\title{
Critical perspectives on network governance in urban regeneration, community involvement and integration
}

\author{
Gerard van Bortel · David Mullins
}

Received: 4 September 2008/Accepted: 4 December 2008/Published online: 18 March 2009

(C) The Author(s) 2009. This article is published with open access at Springerlink.com

\begin{abstract}
Significant claims have been made about the benefits of network governance and management in securing community involvement and assisting social integration in complex urban regeneration programmes. The move from vertical to horizontal forms of coordination, and the assumption of a more equal power distribution between participants, have combined with an emphasis on mutuality and trust to present networks as a promising mechanism for pluriform involvement and collective decision-making. Often this promise runs ahead of the evidence of how network governance functions in practice, the opportunities for different actors to influence the process and the often disappointing outcomes of joint decision-making. This special issue contributes to the 'second generation of research on governance networks' by tackling key questions relating to the sources of governance network failure and success. Building on the articles in this special issue, we explore these questions in relation to urban regeneration, community involvement and the integration of minority groups in The Netherlands, Sweden and England. This article reviews the articles in this special issue from the perspective of Klijn and Skelcher's (2007) four conjectures on democracy and governance networks and Sørensen and Torfing's (2007) four conditions for democratic anchorage. It also suggests ways in which the research agenda on networks in urban regeneration, community involvement and integration might be developed.
\end{abstract}

Keywords Network governance - Urban regeneration · Community involvement · Social integration

G. van Bortel (西)

OTB Research Institute for Housing, Urban and Mobility Studies, Delft University of Technology,

Delft, The Netherlands

e-mail: g.a.vanbortel@tudelft.nl

D. Mullins

Centre for Urban and Regional Studies, University of Birmingham, Birmingham, UK

e-mail: d.w.mullins@bham.ac.uk 


\section{Introduction}

As a result of reforms in public management and governance during the 1980s and 1990s the nature of social housing systems in Europe is changing, replacing hierarchical relationships among actors with market and/or network relations (Mullins and Rhodes 2007, p. 1; Hood 1991; Kickert and Koppenjan 1997). The renewal of deprived neighbourhoods and low-quality housing stock is an important challenge in social housing throughout Europe and network governance is gaining precedence as mode of decision-making to harness the involvement of relevant actors in these processes. Advocates of network governance highlight the necessity of networked forms of decision-making to manage uncertainty, resolve societal problems, access expertise and enable citizen engagement in a complex society with dispersed power and resources (Koppenjan and Klijn 2004). Significant claims have been made about the benefits and efficiency of network governance in securing community involvement and assisting social integration in complex urban regeneration programs (McLaverty 2002; Van Bortel et al. 2007).

The move from vertical to horizontal forms of co-ordination, and the assumption of more equal power distribution between participants has combined with an emphasis on mutuality and trust to present networks as a promising mechanism for pluriform involvement and collective decision-making. Often this promise runs ahead of the evidence of how network governance functions in practice, the opportunities for different actors to influence the process and the often disappointing outcomes of joint decisions. Moreover, there are tensions between network forms of governance and democracy, with the potential for incompatibility, complementarity, transition or instrumentality (Klijn and Skelcher 2007). The concept of 'democratic anchorage' refers to the relationship between governance networks and democracy and the potential for either loose or close coupling.

There is currently a significant stream of research in progress on network governance in fields such as housing, regeneration and social integration in what has been termed a 'second generation of research on governance networks' (Sørensen and Torfing 2005, 2007). It is anticipated that this research will produce more critical and nuanced perspectives on the efficacy of different types of network governance in different contexts. We attempted to access some of this research in progress in the fields of housing, regeneration and integration by convening a workshop at the European Network for Housing Research Conference in Rotterdam in 2007 and by working with authors of papers on urban regeneration, community involvement and the integration of minority groups in The Netherlands, Sweden and England to tease out some of the determinants of network success and failure and to develop some more critical perspectives on the analysis of network governance. ${ }^{1}$ Secondary analysis of these papers is used to inform our argument in this paper.

We will start by introducing network governance and its relationship to democracy in Sect. 2. In Sect. 3 we consider some critiques of network modes of decision-making. Section 4 introduces Klijn and Skelcher's (2007) four conjectures on the relationship between democracy and network governance and the framework developed by Sørensen and Torfing (2007) to explore the notion of democratic anchorage. Section 5 introduces the case studies from the housing regeneration and integration fields and assesses their findings in relation to the competing conjectures and democratic anchorage conditions. Our

\footnotetext{
1 The workshop was on social housing in Europe: Institutional and Organisational Dynamics and the original papers can be accessed at www.enhr2007rotterdam.nl. Selected papers are currently being refereed for a special issue of the Journal of Housing and the Built Environment to be published in 2009.
} 
conclusion (Sect. 6) draws out the main points of comparison and proposes some directions for further research on networks in urban regeneration, community involvement and integration in Northern Europe.

\section{Network governance in urban renewal}

The concept of network governance ${ }^{2}$ is increasing in prominence. Since the hierarchical power of government is waning in many parts of society, the terms 'governance' and 'networks' are used to describe emerging modes of decision-making. Sørensen and Torfing refer to governance networks as a particular type of network and a particular type of governance (2005, p. 9). They define the following key elements:

1. a relatively stable horizontal articulation of interdependent, but operationally autonomous actors;

2. actors interact through negotiations;

3. negotiations take place within a regulative, normative, cognitive and imaginary framework;

4. the framework is self-regulatory within limits set by external agencies;

5. the framework contributes to the production of public purpose.

Since the 1990s a considerable literature on decision-making in networks has been published (De Bruijn and Ten Heuvelhof 1991; Kickert et al. 1997; Klijn 1997; Koffijberg 2005; Rhodes 1997; Scharpf 1993, 1997; Teisman 1998). Among others, Klijn (1997), Van Bortel and Elsinga (2007) and Mullins and Rhodes (2007) have begun to explore the growing role played by networks in systems concerning housing and urban renewal policies and programmes.

Some of these researchers claim that markets and hierarchies are replaced by network modes of decision-making due to the complexity of societies and the wicked nature of problems making network governance the only viable option (Koppenjan and Klijn 2004). Others contend that actors have more freedom to use different coordination mechanisms or even combinations of hierarchy, networks and markets. This is sometimes described as mixed-economy coordination (Bradach and Eccles 1989). These authors argue that each coordination mechanism has its advantages and disadvantages and the viability of a coordination mechanism depends on the characteristics of the actors involved, the issues at stake and context of decision-making (Entwistle et al. 2007).

\section{Governance networks: ambiguity and critique}

Several related critiques are now beginning to emerge of network governance highlighting its ambiguity and problematic relationship with democracy. First there is the view that in many cases the appearance of interdependent networks masks a reality of continued state dominance and steering. Second is the related critique that inequalities of power within networks can lead to quite hierarchical relationships focused on one or more dominant actors. Third is the more subtle observation that the appropriateness and acceptability of

\footnotetext{
2 In this paper we use both 'network governance' and 'governance networks'. In our opinion the meaning of these terms is almost identical, but 'network governance' places slightly greater emphasis on the decisionmaking aspect, while 'governance networks' emphasises the institutional aspect.
} 
network governance depends on the institutional and political context in which the decision-making takes place. All of this suggests potential conflicts between efficient network governance and accountability and democracy.

Besides the failures of coordination mechanisms and the possible mix of market, networks and hierarchies (Entwistle et al. 2007), there is also discussion on the ambiguous nature of decision-making in governance networks. Rhodes (1997) claims that urban regeneration in the UK is characterised by an interdependent network of state and non-state actors that is undermining the power of the state. Davies (2002) insists that the state is still dominant, even if in a highly mediated form, arguing that 'networks' can better be described as 'partnerships', with asymmetrical power relations still favouring the state. Jones and Evans (2006, p. 1494) see a widespread appeal in different political contexts for the emergence of networks between public and private actors, but conclude that in many cases these partnership arrangements are strongly steered by the state.

Swyngedouw (2005) contends that the emphasis on more participatory governance arrangements is decidedly "Janus faced" since networks often favour strong actors over the weaker ones. This is particularly apparent in regeneration and integration partnerships where community partners often enjoy substantially fewer resources than state or private sector partners and are dependent on the willingness of other network members to hear and respond to their agendas. Mullins and Jones (2007) for example explore the extent to which the enormous differences of power and interests between Refugee Community Organisations (RCOs), housing associations and other partners affect the ability to deliver joint outcomes, even within networks specifically constructed to enable power to be shared.

Discussions on the appropriateness of governance networks versus hierarchical steering are influenced by the context in which decision-making takes place. This can be illustrated by the urban renewal approach taken in Naples, Italy. Bull and Jones (2006) contend that urban regeneration in Naples was not aimed at creating an inclusive governance network based on community involvement, but on strengthening legality and accountability of conventional representative democracy (Bull and Jones 2006, p. 768). Traditional governance networks in Naples' urban renewal neighbourhoods were of a very particularistic and non-transparent nature. The municipal efforts to replace this with more hierarchical steering and 'command and control' received large public support due to the widely felt revulsion in Italy at clientelism, corruption and organised crime in Naples (Bull and Jones 2006).

Academic discussions on coordinating mechanisms illustrate that the shift from government to governance is an ambiguous phenomenon. Decision-making in networks of interdependent actors is not always seen as a benign form transcending conflict and power relations, but as an element that can lead to exclusionary and sometimes very particularistic social networks (Mullins and Rhodes 2007). These networks can be efficient, but at the same time profoundly undemocratic and lacking transparency and accountability.

\section{Bringing democratic anchorage back into governance networks}

Network theorists contend that governance networks are a way of responding to complex and wicked societal problems and may be the only viable way of decision-making in a situation with fragmented resources and many interdependent actors (Koppenjan and Klijn 2004). Though maybe an efficient mode of decision-making, governance network are criticised for their lack of attention to the democratic implications of these networks (Sørensen and Torfing 2005). 
Klijn and Skelcher (2007) open up the question of the relationship between network governance and democracy by identifying four distinct conjectures, each with different implications for analysis and practice.

Their first incompatibility conjecture assumes that governance networks conflict with democracy because they are predicated on a different set of institutional rules. Sørensen (2002) identifies four ways in which implicit rules of governance networks may conflict with those of representative democracy: first through a sharing of sovereignty between different levels; second through changing the nature of political representation; third through a more active role for public administrators vis-à-vis elected representatives; and fourth by blurring the separation between the political system and society. In this view governance networks undermine liberal democracy because they often bypass representative democratic institutions.

Klijn and Skelcher's second complementarity conjecture is more optimistic, seeing governance networks as complementing traditional institutions of liberal democracy, contributing to the development of new forms of democracy, and adapting to greater complexity in the nature of decisions and societal fractures by opening up new opportunities and arenas for citizen engagement around the edges of the representative systems. In this view certain managerial issues may be delegated to networks, whilst elected politicians preserve a 'high policy role' and democratic oversight. Thus rather than undermining democracy, networks may enable wider democratic anchorage, involving more groups at different stages of decision processes from agenda setting to implementation, and thereby building social capital (McLaverty 2002).

Klijn and Skelcher's third transitional conjecture suggests that we may be seeing a gradual displacement of representative government by network governance. There are interesting implications here depending on whether the shift is a product of external drivers such as globalisation or internal momentum, whereby once power is delegated to networks, elected politicians have great difficulty reclaiming it. If the latter is the case then the reaction of elected politicians is important. Should they resist an inevitable process in which political values and judgements will be more widely shaped? Or should they seek to adapt their own role to an active process management one in which "democracy is a design task to be implemented in the real life practice of governance networks" (Klijn and Skelcher 2007, p. 18).

Klijn and Skelcher's final instrumental conjecture sees networks as instruments used by dominant actors to reinforce and realise their interests rather than as a process of negotiation with other actors. We have already referred to Davies (2002) in support for the conjecture that the state remains the dominant actor in regeneration policy and that horizontal influence is relatively limited in practice. Skelcher et al. (2005) provide a helpful depiction of different types of sub-national governance networks- 'clubs' are characterised by strong horizontal influences and mutuality; 'polity networks' involve the creation of new political communities (e.g. election of residents to regeneration boards); meanwhile 'agency networks' come closest to those described by Davies in which the network is shaped by national government and autonomy is limited by being integrated into vertical performance management systems that dictate and regulate outcomes to meet national targets. Case studies of regeneration partnerships in England by Skelcher et al. (2005) found that over half were closest to the 'agency network' type.

A new generation of post-liberal theorists on democracy support the complementarity conjecture that governance networks might contribute to the democratisation of societal governance (Sørensen and Torfing 2005, p. 200). But governance networks can only have a positive effect on the democratic functioning of society if these networks are themselves 
democratic. Sørensen and Torfing (2005, pp. 201-213) suggest measuring the democratic performance of governance networks in terms of democratic anchorage. Their criteria for network governance to complement democracy and maintain democratic anchorage are that governance networks should:

1. be subject to control by democratically elected politicians through network design, framing and participation;

2. represent the membership basis of the participating groups and organisations;

3. be accountable to the territorially defined citizenry; and

4. follow the democratic rules specified by a particular grammar or conduct.

\subsection{Anchorage in democratically elected politicians}

The basic rationale of the anchorage of governance networks in democratically elected politicians is to make sure that the outcomes in these networks are in line with the popular will expressed by the political majority in elected assemblies. To do this one needs to rethink the notion of political control. Unconstrained overruling of decisions made in governance networks is not compatible with one of the main characteristics of governance networks: their capacity for self-regulation. Therefore political control has been redefined as the concept of meta-governance. Meta-governance can be described as the attempts of politicians, administrators or other governance networks to construct, structure and influence the game-like interaction within governance networks. Meta-governance facilitates and constrains the decision-making processes in self-regulation networks without using hierarchical control. However, network governance always takes place in the 'shadow of hierarchy' because meta-governance is in last instance sustained by the underlying threat of government interventions. Based on Kickert and Koppenjan (1997, p. 53) Sørensen and Torfing (2005, pp. 203-204) distinguish three different forms of meta-governance: (1) network design, (2) network framing and (3) network participation.

Network design involves attempts to influence which actors participate in specific governance networks and to selectively empower some actors by giving them important resources that turn them into key players in the network. Network framing involves the formulation of goals and objectives pursued by governance networks. Network framing can include the allocation of resources and the legal framework to guide the interactions within the governance network. Network participation involves direct participation of elected politicians in order to get first-hand knowledge of the network process and exert their political authority.

\subsection{Anchorage in the membership basis of participating groups and organisations}

In order to obtain democratic legitimacy, groups and organisations participating in governance networks should constitute a fair representation of directly affected people. Based on Pitkin (1967) and Laclau (1993), Sørensen and Torfing (2005, p. 205) contend that the classical notion of representation (an unbiased one-to-one representation of a pre-given interest or preference in network-based decision-making) is problematic and theoretically flawed. There will always be discrepancies between the way opinions are articulated by those who are represented and the way representation is constructed in the governance network: the performative act of representation. The crucial question is whether those whom the representatives claim to represent identify with the discursive form of representation. Sørensen and Torfing (2005, p. 207) divide the democratic anchorage of 
representation in three aspects: (1) the ability of members of a group to select and instruct their representatives, (2) the ability of members to form an informed opinion about their representatives' performance in the governance network and (3) to express different opinions and criticise the representatives' performance in the governance network.

The main challenge is to balance the pre-given mandate of representatives with the freedom to negotiate in the decision-making process. If representatives are tied 'by hands and feet' it is almost impossible to participate in the give and take forms of decisionmaking in networks.

\subsection{Anchorage in a territorially defined citizenry}

Governance networks must not only include representatives of all the people directly affected by decisions, they must also be accountable to a wider citizenry, which is affected indirectly. In the example of urban renewal networks territorially defined citizens and communities should be able to hold the governance network accountable for its policy output and outcomes. The classical notion of public accountability is difficult. Network actors cannot be expelled at the next election because they are not elected but (self-) appointed, and since there might not be anybody to replace them. For instance a housing association mismanaging an urban renewal project cannot be removed because they often own significant assets within the neighbourhood. Often the problem is not so much the removal of such interests, but their activation to get involved within these territorially based networks by attracting their attention from other networks and policy games that they may be involved in.

Sørensen and Torfing argue that these difficulties should not prevent one from seeking solutions to facilitate public contestation of decisions made by governance networks. Public contestation basically involves a public account by the governance network of why, how and with what result they did what they did. Furthermore, they must engage in public dialogue with critical citizens. If participation of citizens remains wanting, critical opponents can also be found in mass media, scientific and professional organisations, interest organisations, social movements and other governance networks (Sørensen and Torfing 2007, pp. 209-210). Public contestation can only succeed if three crucial requirements are met: (1) transparency by the governance network in presenting decisions and results in a comprehensive, informative and for lay people accessible format, (2) access of citizens or other stakeholders to a public dialogue with the governance network and (3) responsiveness on the part of the governance network without scorn, ridicule or other dismissive attitudes towards critical opponents.

\subsection{Anchorage in democratic rules and norms}

Internal processes and interactions within governance networks should live up to commonly accepted democratic standards, rules and norms. Sørensen and Torfing (2005, p. 212) point out that these rules are subject to endless contestation. Furthermore they contend that rules are structurally ambiguous and can only be followed through re-articulation and re-enactment. So any list of rules and norms is by definition incomplete. Sørensen and Torfing mention three kinds of normative regulations that relate to the formation, functioning and output of governance networks: (1) inclusion of all relevant and affected actors and the construction of an open-ended policy discourse, (2) democratic deliberation based on voice and exit, respect for other people's opinions, commitment to reach a 'rough' consensus (which includes the possibility to 'agree to disagree'), transparency about the 
terms of the debate, (3) government networks must improve the future system of governance by enhancing social and political justice, empower participating actors and stimulate an active search for new forms of democracy to improve public decision-making processes.

\section{Democratic anchorage in housing, regeneration and integration networks}

\subsection{Introducing the cases}

Governance networks and the network approach to analyse decision-making in governance networks are getting more prominent in housing studies, especially in complex decisionmaking processes like urban regeneration and social integration. The focus in these studies is still very much on the efficiency and effectiveness of policies, decision-making processes and their outcomes. The management of governance networks has only recently become an important theme in this research (see Mullins and Rhodes 2007). Even fewer studies have yet begun to explore the democratic anchorage of governance networks, but this would be an important development in this research field.

We will use Klijn and Skelcher's four conjectures and Sørensen and Torfing's four democratic anchorage points to critically assess the level of democratic anchorage in five case studies derived from the articles in this special issue (see Table 1).

All papers discuss decision-making processes in housing systems, some explicitly use network governance frameworks to analyse decision-making. Additionally almost all papers have in common that relatively weak actors were part of the decision-making process, or their position in urban renewal governance networks was an issue. Four papers contain research results on urban renewal including community involvement. Two papers focus on social integration issues relating to refugee communities and urban renewal.

\subsection{Urban renewal, Arnhem}

In the urban renewal project described by Buitelaar and De Kam (2007) the local authority and a private investor developed plans for a specific brown field location in the city of Arnhem in The Netherlands. The municipality and the private developer had deliberately

Table 1 Overview of papers used for the secondary analysis (Drafts of these articles were presented at the 2007 conference of the European Network of Housing Research in Rotterdam)

Title Authors

Papers on urban renewal and community involvement

Steering local housing production: evaluation of the performance of governance structures (par. 5.2)

Deadlocks and breakthroughs in urban renewal: a network analysis in Amsterdam (par. 5.3)

Network governance in action: the case of Groningen. Complex decision-making in urban renewal (par. 5.4)

Papers on refugee integration

Refugee integration and access to housing, a network management perspective (par. 5.5)

Neighbourhood network governance, ethnic organization, and the prospects for political integration (par. 5.6)

Buitelaar, E. and De Kam, G.

Haffner, M. and Elsinga, M.

Van Bortel, G.

Mullins, D. and Jones, P.

Hertting, N. 
chosen not to include residents in the first stages of the planning process and wanted to adapt a 'design-announce-defend' approach because they wanted to check the feasibility of the plan before going public. The local authority assumed that the neighbouring residents would be content with the planning outcomes because the plan included the replacement of a supermarket (removing all the nuisances attached with these kinds of facilities) with housing.

Strong opposition from neighbouring residents emerged after public presentation of the plans. The alderman responsible for this project nevertheless decided to start the formal planning procedure to enable the execution of the plan. However, the city council's planning committee (consisting of elected local politicians) refused to submit the plans for formal approval due to the opposition of residents. Consequently the planning had to start all over again in a more participatory way with adapted municipal goals. Buitelaar and De Kam's reconstruction of decision-making in Arnhem creates the impression that including residents in the planning process was not intended to give residents' objectives full attention. The city assumed that resident participation would result in a better supported plan that would pass formal planning procedures more quickly and would lead to lesser claims for planning damage compensation. Adaptations of the plan originating from residents are described as 'a price to be paid' and 'buying consent' and not as natural outcomes of a democratically anchored policy process.

This case provides an example of an initial perception of incompatibility between democracy and network governance. It traces a gradual transition from one to the other as elected politicians responded to opposition. They did so by invoking meta-governance tools. These were used to influence network design through giving residents a stronger position and by using their hierarchical power not to start formal approval procedures until the objections of residents were properly addressed. This led to a different network framing because the municipal goals for the redevelopment area were modified to accommodate the residents' objectives.

\subsection{Urban renewal, Amsterdam}

The paper by Haffner and Elsinga (2007) describes the deadlocks and breakthroughs in the urban renewal of two neighbourhoods in Amsterdam North. Policy development became bogged-down because residents and the housing associations were not able to reach an agreement on the urban renewal interventions. The closedness of actors to each other's arguments and objectives prevented a fruitful dialogue. Each actor commissioned their own report from external experts to prove that the other actors were wrong. The project also had a difficult start because residents were initially not involved in the planning decisions and had to contest the plans developed by the housing association from outside the governance network. This contrasts with Sørensen and Torfing's democratic anchorage criterion that groups and organisations participating in governance networks should constitute a fair representation of directly affected people. The difficulties in reaching an agreement on urban renewal interventions in Amsterdam North are perhaps surprising considering that the authors describe the 'culture of compromise' as a typical Dutch phenomenon.

To escape the impasse in the governance network and on initiative of elected politicians of the district council of Amsterdam North, a special negotiation team was formed with independent chairs and representatives from all parties involved (local authority, residents and housing associations). An explicit set of rules was agreed upon to facilitate decisionmaking but also to increase the level of democratic anchorage. To make sure tenants could 
fully participate in decision-making professional actors (e.g. housing associations and local authority) agreed not to use technical jargon and to be open and forthcoming about the pros and cons of proposals. Actors had to commit themselves to working towards consensus and to respect and try to understand the viewpoints of other actors.

This case could also be interpreted as a shift from a hierarchical to a network governance perspective by powerful actors and the adoption of meta-governance tools. Perhaps for instrumental reasons to maintain their own interests, elected politicians decided to redesign part of the network (by introducing the negotiation team and making tenant representatives part of the network); they also emphasised democratic norms of negotiation.

\subsection{Urban renewal charter, Groningen}

The paper by Van Bortel (2007) analysed decision-making on urban renewal policy in the city of Groningen in the North of The Netherlands. The paper focused on the recent renewal of an urban regeneration charter between the local authority and housing associations. Collaboration between these parties on urban renewal issues goes back more than a decade but lately became, according to Van Bortel, more complicated due to an expanding number of policy issues that are included in urban renewal policy. From a very 'bricks-and-mortar' approach urban renewal now also includes more social (e.g. social cohesion, health issues, crime prevention) and economic objectives (e.g. tackling longterm unemployment). The increasing number of policy issues and actors involved in the decision-making led to conflicts and stagnation of decision-making. To overcome this decision-making impasse a number of meta-governance interventions were taken targeting network design, network framing and network participation. Interventions were aimed at organising a special 2-day policy conference in 2006 to bring all relevant actors together from the local authority administration and housing associations to discuss hot issues that blocked the renewal of the urban regeneration charter. This form of network design was specifically envisaged to include officials from different hierarchical levels and participating organisations to facilitate more lateral interactions. So not only the chief executives of housing associations and top level civil servants from municipal departments, but also officials from secondary hierarchical levels in the organisations attended the policy conference. Citizens from Groningen did not participate in this round of decision-making, but it was clear from the outset that citizens would be consulted on the outcomes of the policy conference and the text of the new urban renewal charter.

In this case there was from the start an expectation that network governance would complement democracy, but the emergence of blockages between the network actors led to meta-governance interventions in which elected politicians (the three aldermen responsible for the policy fields that were involved in the new urban renewal charter) had an important role in the design (e.g. the structure of the policy conference and its participants) and the framing (e.g. the aims) of the policy conference. In addition the aldermen also participated in the decision-making at crucial moments during the policy conference.

\subsection{Accommodate programme, refugee integration, England}

Mullins and Jones' (2007) paper on the Accommodate project contains several examples of initiatives to increase democratic anchorage in five local partnerships by improving housing and support options for refugees, empowering RCOs, and changing housing policies. The Housing Associations Charitable Trust (hact) partly funded the local 
partnerships and was a central actor in the governance network. Hact is described in the paper as an "ace networker" that undertook several meta-governance initiatives based on the belief that real benefits could be achieved by building partnerships between newly formed RCOs and Housing Associations at the local level in five cities. The project aimed at increasing refugee groups' capacity to engage in partnerships and local decision-making processes and create a sustainable leadership for these organisations.

The accommodate project connects well to several points of democratic anchorage as described by Sørensen and Torfing. Hact was very active in meta-governance activities by deciding on the aims of the Accommodate project (network framing) and the actors that could participate (network design). These meta-governance interventions by hact were only loosely coupled with local democratic structures in the five cities and failed to engage directly with private landlords, who are the largest providers of housing for asylum seekers and refugees. However, they contributed to democratic anchorage by empowering RCOs to engage productively with much stronger Housing Associations. The local Accommodate partnerships also promoted another (post-liberal) democratic norm: accountability. Actors were not only accountable to hact as funder, but also to their local partners. Hact was active in emphasising democratic norms, creating a common vision and negotiating rather than imposing operating procedures on the five local partnerships.

Steering in the 'shadow of hierarchy' clearly played a part in the Accommodate project. Mullins and Jones contend that part of the reason for the programme was a perceived failure of the democratic process to manage the relationship between refugee integration and housing policies. The dominant position of Hact was not based on democratic legitimised power but on its value stance as a relationship funder. The goals of the Accommodate project were influenced by hact's national policy but also by its own dependence on grant givers such as the Big Lottery, Caloust Gulbenkian Foundation and the European Refugee Fund with whom a priori goals are agreed.

In this case there was a strong emphasis on the compatibility of network governance with democracy and on stimulating democratic practice within the network. Hact is the dominant actor in the Accommodate governance network and uses network instruments (like focusing on common interest, reciprocity and horizontal forms of collaboration) not because it is forced to do so due to interdependencies, but as part of its values and ethos.

\subsection{Prospects for political integration of ethnic organisations in Sweden}

Hertting (2007) takes a closer look at ethnic organisations and their capacity to increase their political influence in neighbourhood governance networks. This subject is closely connected with Sørensen and Torfing's fourth democratic anchorage point: democratic rules and norms. Hertting presents two different mechanisms for political integration through ethnic organisations: (1) the collective articulation mechanism and (2) the individual development mechanism.

Hertting begins by describing well-established structures of network modes of decisionmaking in urban regeneration and integration policy in Sweden. He illustrates this with examples from Botkyrka, a suburban city near Stockholm. Additional—clearly post-liberal-network modes of democratic participation have been introduced in this city. Elected politicians from the local council are developing neighbourhood dialogue forums for residents. This initiative is a clear example of meta-governance where elected politicians both shape and participate in governance networks.

Hertting contends that participation of ethnic minority groups in urban renewal can induce a more professional and centralised organisation within ethnic associations 
themselves. In order to perform their role, association leaders must be able to take part in sometimes very complex negotiations with full-time officials from local authorities and social landlords. Network negotiators from ethnic minority organisations need strategic skills and discretionary power in order to successfully negotiate in networks. This can lead to a split between these representatives/negotiators and the members they represent thereby weakening the democratic anchorage in the membership basis of participating groups and organisations. Somewhat paradoxically it seems that efficient network governance both enhances and is enhanced by hierarchical structures within the networking organisations (see Hertting 2003, p. 95). There appears to be a trade-off between the networking power of an ethnic minority organisation, requiring a degree of centralisation, and the democratic participation of members of the association.

Ethnic minority organisations participating in governance networks can work as a 'school of democracy' and form an arena for promoting political skills, political efficacy, self-confidence, contact networks and trust in other individuals and in collective decisionmaking in general and thereby strengthen democratic norms and values. Hertting contends that the development of these skills and values is heavily dependent on the mode of interaction within the ethic minority organisations. Ethnic associations that encourage participation of their members produce political development skills, but to be successful in network negotiations, these organisations require centralisation and professionalism that could restrict the possibilities to practise skills of members in real decision-making. Hertting identified a more indirect form of transfer of political and democratic skills, based on sub-elite integration (Etzioni-Halevy 1993) According to this line of argument, political efficacy, trust and skills developed among representatives in governance networks will spread downwards within the represented groups.

Hertting concludes that there are both potentials and problems attached to the participation of ethnic minority groups in neighbourhood governance networks. He notes that participation of these groups can increase collective and individual political and democratic skills and values and thereby increase democratic anchorage. This suggests that while network governance can be seen as compatible with democracy, there are subtle ways in which instrumental forces begin to transform the nature of the agents involved in governance networks that can work to undermine their own democratic practices.

\section{Conclusions and discussion}

We have used the four conjectures put forward by Klijn and Skelcher (2007) and the four criteria for democratic anchorage as described by Sørensen and Torfing (2005) to assess the policy development in the articles. The outcomes of this assessment are mixed and necessarily limited by the evidence available from secondary research papers based on a variety of theoretical positions and methodologies. However, we believe that this analysis provides a useful way of exploring and synthesising existing work on the topic of network governance in housing, regeneration and integration in Northern Europe.

Taking the four conjectures first (see Table 2), we may distinguish between the starting point of the key actors involved in the case studies and the changes that emerged as these case studies developed.

Key actors in some case studies started from a clear perception of complementarity between democracy and network governance (notably the Groningen regeneration case study in The Netherlands, the regeneration and integration policy case study in Botkyrka, Sweden and the Accommodate refugee partnership model in England). In other cases there 
appears to have been an initial reluctance by powerful state and non-profit actors to engage with network forms of organisation, perhaps because of a perceived incompatibility with democracy (in Arnhem and in Amsterdam). It appears that such network organisation as existed operated in the shadow of hierarchy.

However, the case studies indicate that such relationships do not remain static, but can be subject to change. Evidence of transition over time towards more network-based approaches was found in several of the case studies. In both Arnhem and Amsterdam this took the form of intervention by elected members to activate resident interests in decisionmaking using meta-governance network management tools. In Groningen too elected politicians became involved in meta-governance but in this case to overcome blockages that had arisen within a complementary model of network governance and democracy. While such interventions are consistent with the complementarity conjecture, there is a suspicion that in some cases (e.g. Amsterdam) there was a more instrumental interest by politicians in restoring their own dominance in decision processes rather than in oiling the wheels of collaborative networks. The Swedish case study provides a further example of transition to network governance and instrumentalism, but in this case the very success of engagement between democracy and integration networks had produced a change in the nature of the minority ethnic organisations engaging in these networks. In order to engage in conformance with external democratic and network processes, minority ethnic organisations were being transformed internally into more hierarchical and less democratic organisations.

Overall, the case studies appear to indicate a degree of complementarity between network governance and democracy. Meta-governance approaches by elected authorities and in one case by an external agency (hact) emerged to manage transitions from democratic to network forms of organisation and to overcome blockages that had arisen in the absence of strong hierarchical steering. If this evidence for the complementarity conjecture holds true, then it is relevant and important to go on to explore conformance with Sørensen and Torfing's criteria for democratic anchorage of governance networks.

Turning to the criteria for reinforcing complementarity between democracy and network governance (Table 3) we agree with Sørensen and Torfing (2005, p. 214) that demanding a perfect and uncompromising compliance with all rules and norms at all times might seriously damage the efficiency of decision-making. So it is important to find a pragmatic balance between efficiency and democracy.

The two papers on refugee and ethnic minority participation (in England and Sweden) focused on improving capabilities of marginalised groups to participate in governance networks. In both cases network design initiatives were used to strengthen the position of minority groups within the governance network. In Botkyrka alignment with external democratic structures had interesting implications for democratic practice within minority community organisations as discussed above. In contrast with the Swedish case, the English Accommodate project meta-governance initiatives did not originate from elected politicians but from a relationship with a funding organisation, hact, operating at national level but aiming to facilitate local political integration. The democratic mandate of hact is not clear; however, Mullins and Jones suggest that it was in 'the right place at the right time' to bridge the gap between refugee dispersal and housing policy that had emerged in the English political system where there appeared to have been a 'failure of political will' to make these links. Moreover, hact enjoyed strong legitimacy with both the refugee community and housing sectors as a result of 45 years of work with both sectors and its commitment to "pioneer housing solutions for people on the margins". 


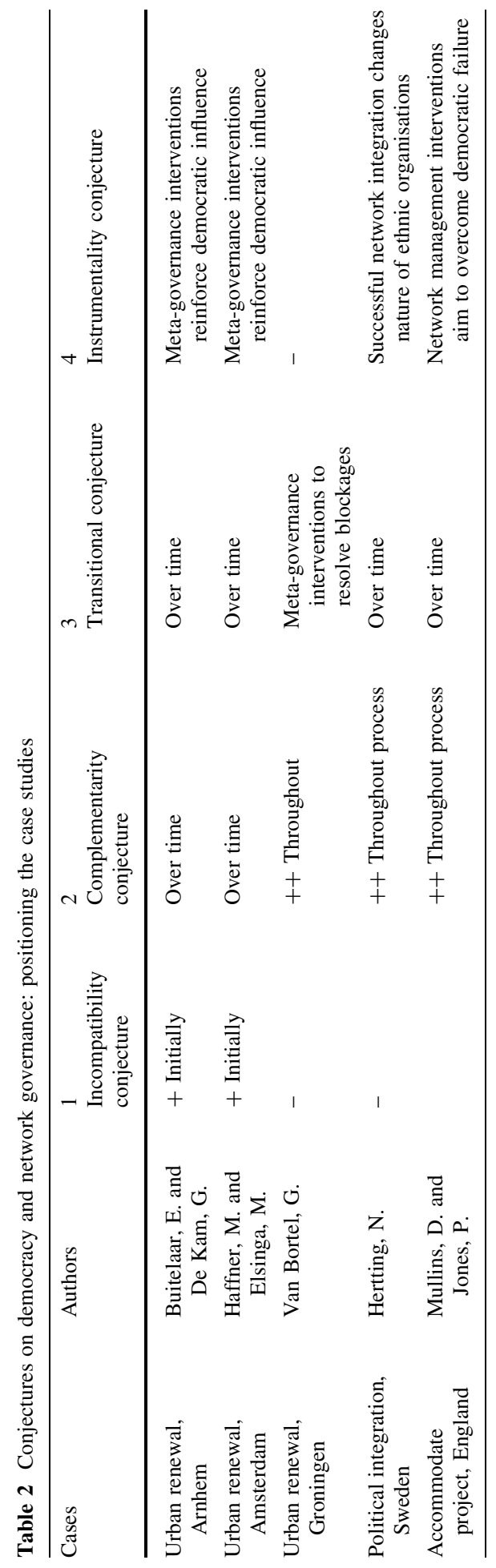


Table 3 Democratic anchorage assessment of case studies

\begin{tabular}{|c|c|c|c|c|c|}
\hline Cases & Authors & $\begin{array}{l}1 \\
\text { Anchorage in } \\
\text { democratically } \\
\text { elected } \\
\text { politicians }\end{array}$ & $\begin{array}{l}2 \\
\text { Anchorage in } \\
\text { membership } \\
\text { basis of } \\
\text { participating } \\
\text { groups and } \\
\text { organisations }\end{array}$ & $\begin{array}{l}3 \\
\text { Anchorage in } \\
\text { a territorially } \\
\text { defined } \\
\text { citizenry }\end{array}$ & $\begin{array}{l}4 \\
\text { Anchorage } \\
\text { in democratic } \\
\text { rules and norms }\end{array}$ \\
\hline $\begin{array}{l}\text { Urban renewal, } \\
\text { Arnhem }\end{array}$ & $\begin{array}{c}\text { Buitelaar, E. and } \\
\text { De Kam, G. }\end{array}$ & ++ & $\mathrm{n} / \mathrm{a}$ & $\mathrm{n} / \mathrm{a}$ & - \\
\hline $\begin{array}{c}\text { Urban renewal, } \\
\text { Amsterdam }\end{array}$ & $\begin{array}{c}\text { Haffner, M. and } \\
\text { Elsinga, M. }\end{array}$ & ++ & + & + & ++ \\
\hline $\begin{array}{c}\text { Urban renewal, } \\
\text { Groningen }\end{array}$ & Van Bortel, G. & + & + & + & $\mathrm{n} / \mathrm{a}$ \\
\hline $\begin{array}{l}\text { Political } \\
\text { integration, } \\
\text { Sweden }\end{array}$ & Hertting, N. & ++ & + & + & ++ \\
\hline $\begin{array}{l}\text { Accommodate } \\
\text { project, England }\end{array}$ & $\begin{array}{l}\text { Mullins, D. \& } \\
\text { Jones, P. }\end{array}$ & - & + & + & ++ \\
\hline
\end{tabular}

Note that not all cases covered the four democratic anchorage points. In these cases we have used the qualification non-available (n/a)

The Arnhem case presents a more liberal democratic view-point on the role of elected politicians. City administration officials in this case initially undertook the redevelopment of the infill site in collaboration with a project developer. Elected politicians from the city council used formal planning procedures to include residents in the governance network. It appears that professional actors found the inclusion of residents in the governance network more of a burden than a blessing. Adaptations to the plan originating from resident involvement were described as 'a price to be paid' and as 'buying consent', not as natural outcomes of a democratically anchored policy process.

In Amsterdam there was a clearer commitment to meta-governance interventions to promote engagement with residents by agreeing more inclusive rules such as consensus working and plain speaking by officials.

The Groningen case showed a clear commitment to territorially based anchorage in each of the priority neighbourhoods. A prior commitment to network governance led to a democratic intervention to overcome blockages between professional actors prior to further engagement with the citizens. However, because the case study focused on this stage of the process there was little evidence of anchorage in democratic rules and norms. It was anticipated that this would follow through consultation on the text of a new urban renewal charter.

There is an emerging research agenda which it is important to build on to develop more sophisticated and nuanced accounts of network governance and the relationship with democracy. We believe that the following learning points need to be taken into account by researchers in the field of housing, regeneration and integration. First, accounts should identify the extent to which network governance operates in practice and the extent to which networks operate 'in the shadow of hierarchy' as appeared to be the case in at least two of the case studies explored here. Second, we need to explore the extent to which network governance is seen by the actors involved as incompatible or complementary to democracy and how these views change over time. It is important to identify the a priori 
assumptions and to distinguish these from patterns that emerge as policy games develop within governance networks. Third, it is important to gather evidence of the ways in which networks are linked to democracy both in terms of system linkages and organisational practices.

Inevitably our attempt to apply these principles to analysis of studies that had been conducted with rather different goals and methods raises possibilities of misinterpretation. We are also conscious of the rather narrow empirical base of these secondary accounts covering just three Northern European states. However, we hope that further work will now be undertaken in a wider range of contexts to develop critical second generation of research on network governance within the field of housing, regeneration and integration.

Open Access This article is distributed under the terms of the Creative Commons Attribution Noncommercial License which permits any noncommercial use, distribution, and reproduction in any medium, provided the original author(s) and source are credited.

\section{References}

Bradach, J. L., \& Eccles, R. G. (1989). Price, authority and trust; from ideal types to plural forms. Annual Review Sociology, 15, 97-118.

Buitelaar, E., \& De Kam, G. (2007). Paper presented at the ENHR 2007 conference in Rotterdam [Accessible at www.enhr2007rotterdam.nl].

Bull, A. C., \& Jones, B. (2006). Governance and social capital in urban regeneration: A comparison between Bristol and Naples. Urban Studies, 43(4), 767-786.

Davies, J. S. (2002). The governance of urban regeneration: A critique of the governing without government thesis. Public Administration, 80(2), 301-322.

De Bruijn, J. A., \& Ten Heuvelhof, E. F. (1991). Sturingsinstrumenten voor de overheid; over complexe netwerken en een tweede generatie sturingsinstrumenten [Steering instruments for the state, on complex networks and second generation steering instruments]. Leiden: Stenfert Kroese.

Entwistle, T., Bristow, G., Hines, F., Donaldson, S., \& Martin, S. (2007). The dysfunctions of markets, hierarchies and networks in meta-governance of partnership. Urban Studies, 44(1), 63-79.

Etzioni-Halevy, E. (1993). The elite connection. Problems and potential of Western democracy. Cambridge, MA: Polity Press.

Haffner, M. \& Elsinga, M. (2007). Paper presented at the ENHR 2007 conference in Rotterdam [Accessible at www.enhr2007rotterdam.nl].

Hertting, N. (2003). Samverkan på spel. Rationalitet och frustration i nätverksstyrning och svensk stadsdelsförnyelse [Games local actors play: Rationality and frustration in network governance and Swedish neighborhood renewal]. Stockholm: Egalité.

Hertting, N. (2007). Paper presented at the ENHR 2007 conference in Rotterdam [Accessible at www. enhr2007rotterdam.nl].

Hood, C. C. (1991). A public management for all seasons. Public Administration, 69(1), 3-19.

Jones, P., \& Evans, J. (2006). Urban regeneration, governance and the state: Exploring notions of distance and proximity. Urban Studies, 43(9), 1491-1509.

Kickert, W. J. M., Klijn, E. H., \& Koppenjan, J. F. M. (Eds.). (1997). Managing complex networks; strategies for the public sector. London: Sage Publications.

Kickert, W. J. M., \& Koppenjan, J. F. M. (1997). Public management and network management: An overview. In W. J. M. Kickert, E. H. Klijn, \& J. F. M. Koppenjan (Eds.), Managing complex networks; strategies for the public sector. London: Sage Publications.

Klijn, E. H. (1997). Policy networks: An overview. In W. J. M. Kickert, E. H. Klijn, \& J. F. M. Koppenjan (Eds.), Managing complex networks; strategies for the public sector. London: Sage Publications.

Klijn, E. H., \& Skelcher, C. (2007). Democracy and governance networks, compatible or not? Public Administration, 85(3), 587-608.

Koffijberg, J. (2005). Getijden van beleid: Omslagpunt in volkshuisvesting. Over de rol van hiërarchie en netwerken bij grote veranderingen [Tides of policy: Turning points in public housing. On the role of hierarchy and networks in the management of change]. Delft: Delft University Press.

Koppenjan, J. F. M., \& Klijn, E. H. (2004). Managing uncertainties in networks. London: Routledge. 
Laclau, E. (1993). Power and Representation. In M. Poster (Ed.), Politics, theory and contemporary culture (pp. 277-296). New York: Columbia University Press.

McLaverty, P. (Ed.). (2002). Public participation and innovations in community governance. Aldershot: Ashgate.

Mullins, D. \& Jones, P. (2007). Paper presented at the ENHR 2007 conference in Rotterdam [Accessible at www.enhr2007rotterdam.nl].

Mullins, D., \& Rhodes, M. L. (2007). Editorial special issue on network theory and social housing. Housing Theory and Society, 24(1), 1-13.

Pitkin, H. F. (1967). The concept of representation. Berkeley: University of California Press.

Rhodes, R. A. W. (1997). Understanding governance: Policy networks, governance, reflexivity and accountability. Buckingham: Open University Press.

Scharpf, F. W. (Ed.). (1993). Games in hierarchies and networks: Analytical and empirical approaches to the study of governmental institutions. Frankfurt am Main: Campus-Verlag; Boulder, CO: Westview Press.

Scharpf, F. W. (1997). Games real actors play: Actor-centered Institutionalism in policy research. Boulder: Westview Press.

Skelcher, C., Mathur, N., \& Smith, M. (2005). The public governance of collaborative spaces: Discourse, design and democracy. Public Administration, 83(3), 573-596.

Sørensen, E. (2002). Democratic theory and network governance. Administrative Theory and Praxis, 24(94), 693-720.

Sørensen, E., \& Torfing, J. (2005). The democratic anchorage of governance networks. Scandinavian Political Studies, 28(3), 195-218.

Sørensen, E., \& Torfing, J. (Eds.). (2007). Theories of democratic network governance. London: PalgraveMacMillan.

Swyngedouw, E. (2005). Governance innovation and the citizen: The janus face of governance-beyond-thestate. Urban Studies, 42(11), 1991-2006.

Teisman, G. R. (1998). Complexe besluitvorming, een pluricentrisch perspectief op besluitvorming over ruimtelijke investeringen [Complex decision-making, a pluri-centric perspective on decision-making in spatial investments]. The Hague: Elsevier.

Van Bortel, G. A. (2007). Network governance in action: The case of Groningen, paper presented at the ENHR 2007 conference in Rotterdam [Accessible on www.enhr2007rotterdam.nl].

Van Bortel, G. A., \& Elsinga, M. A. (2007). Network perspective on the organization of social housing in The Netherlands: The case of urban renewal in The Hague. Housing Theory and Society, 24(1), 32-48.

Van Bortel, G. A., Van Bueren, E., Van Eeten, M., Elsinga, M., Kerpershoek, E. (2007). Rhetoric of success in Dutch urban renewal: The role of personal chemistry and trust in networks. Paper presented at the ENHR 2007 conference in Rotterdam [Accessible at www.enhr2007rotterdam.nl]. 